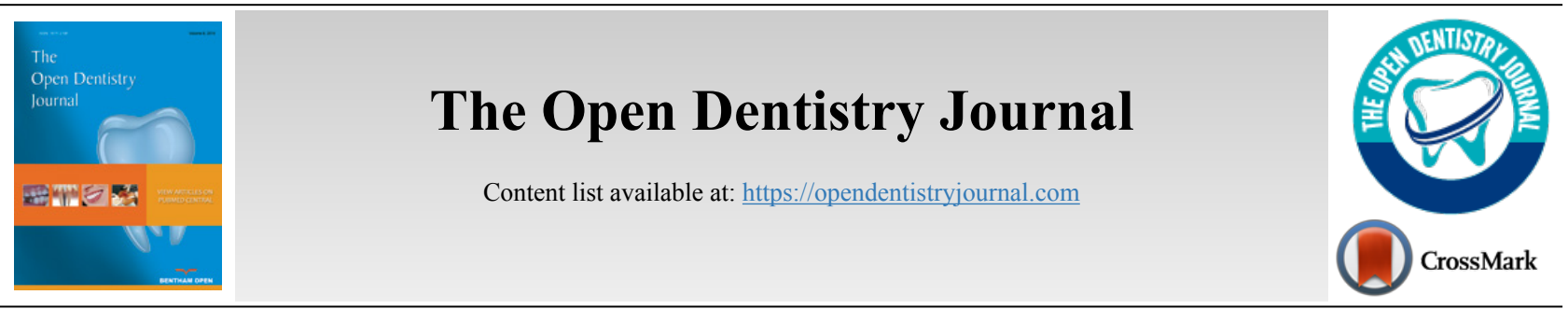

RESEARCH ARTICLE

\title{
Effect of Clinical Use and Sterilization Process on the Transition Temperature Range of Thermally NiTi Alloys
}

Bruno da Silva Vieira ${ }^{1}$, Rodrigo H. Cançado ${ }^{2, *}$, Karina M.S. Freitas ${ }^{3}$, Fabrício P. Valarelli ${ }^{3}$, Renata C. Gobbi ${ }^{3}$ and Ricardo C. Gobbi de Oliveira ${ }^{3}$

${ }^{1}$ Department of Orthodontics, Bauru Dental School. University of São Paulo, Brazil / Alameda Octávio Pinheiro Brisolla 9-75, ZIP CODE 17012-901, Cidade Universitária, Bauru, São Paulo, Brazil

${ }^{2}$ Department of Restorative Dentistry, Discipline of Orthodontics, Federal University of Minas Gerais (UFMG) / Belo Horizonte, Minas Gerais, Brazil

${ }^{3}$ Department of Orthodontics, Uningá University Center. Rodovia PR 317, 6114, ZIP CODE 87035510, Maringá, Paraná, Brazil

\section{Abstract: \\ Background:}

Thermally activated nickel-titanium wires have been widely used by orthodontists due to more constant forces, generation over longer activation spans, greater resistance to permanent deformation, superelasticity characteristics when cyclically loaded, better spring-back and less hysteresis.

\section{Objective:}

The purpose of this study was to evaluate the influence of clinical use and sterilization process on the Transition Temperature Range (TTR) of thermoset nickel-titanium wires using Differential Scanning Calorimetry (DSC).

\section{Methods:}

Sections from four nickel-titanium wires $(0.019 \times 0.025$-inch $)$ belonging to four different brands were assessed in four different states. Two of the wires were assessed in the "as received" state, one after 60 days of clinical use, and one after 60 days of clinical use and subjected to a sterilization process (autoclaving). The segments of each archwire were tested using DSC at temperatures ranging from $-80^{\circ} \mathrm{C}$ to $150^{\circ} \mathrm{C}$ at a rate of $10^{\circ} \mathrm{C} / \mathrm{min}$.

Results:

All the nickel-titanium memory thermoset wires presented with desirable property for clinical use. The shape memory property was not influenced by clinical use and sterilization process.

\section{Conclusion:}

There was no change in TTR of the nickel-titanium wires after clinical use and sterilization.

Keywords: Orthodontic wires, Calorimetry, Materials testing, Differential scanning calorimetry, Sterilization, Alloys.

\section{Article History} Received: February 22, 2019 Revised: June 11, 2019 Accepted: July 04, 2019

\section{INTRODUCTION}

Nickel-Titanium (NiTi) wires were introduced to orthodontics in the 1970s because they presented with desirable mechanical properties for orthodontic movement, such as flexibility, low modulus, high resilience, and shape memory, thereby allowing the wires to return to their original shape upon deformation and promoting alignment of the teeth [1].

\footnotetext{
* Address correspondence to this author at the Department of Restorative Dentistry, Discipline of Orthodontics, Federal University of Minas Gerais (UFMG), Av. Presidente Antônio Carlos, 6627, Pampulha, Belo Horizonte - MG -31270-901, Brazil; Tel: +55 31 3409-2426; E-mail: rohercan0207@gmail.com
}

Since then, several studies have been conducted to enhance the physical properties of these archwires with the aim of improving their use in clinical practice. These studies resulted in the development of a new NiTi wire, which had both shape memory characteristics and superelasticity $[2,3]$.

Thermally activated NiTi wires belong to the new generation and are characterized by their thermoelastic effect (shape memory), which is related to the Transition Temperature Range (TTR) of the alloy releasing low and continuous forces even in large deflections. The complete transformation of martensite to austenite occurs at a certain temperature called 
the Austenite Finish Temperature (Af). This Af temperature should correspond to a temperature of the oral cavity. This is particularly important in orthodontics because it determines the mechanical performance of the NiTi archwire during treatment $[4,5]$.

Nowadays, thermally activated NiTi wires are widely used by orthodontists owing to several factors, including the generation of constant forces over longer activation spans, high resistance to permanent deformation, superior stability, good superelasticity characteristics when cyclically loaded, improved spring-back properties, and low hysteresis. The desirable mechanical properties of NiTi alloy wires and their relatively high cost have prompted many clinicians to recycle these wires. In a survey conducted by Buckthal et al. it was noticed that approximately $52 \%$ of the orthodontists who use NiTi wires recycle them [6]. The aim of the present study was to evaluate the influence of the clinical use and sterilization process on TTR of thermally activated NiTi archwires using the Differential Scanning Calorimetry (DSC) method.

\section{MATERIALS AND METHODS}

The study was conducted on four segments $(0.019 \times 0.025$ inch) of thermally activated NiTi wires from four commercial brands: NeoSentalloy F200 (GAC, Bohemia, USA); Copper NiTi $35^{\circ} \mathrm{C}$ (Ormco, Glendora, USA); Flexy Thermal $35^{\circ} \mathrm{C}$ (Orthometric, Marília, Brazil), and Heat Activated NiTi (Highland Metals, San Jose, USA). Two of the arch wires were used "as received," one after 60 days of clinical use, and one after 60 days of clinical use and subjected to sterilization process using autoclaving (Table 1).

Table 1. Thermally activated Nickel-Titanium wires used in the study.

\begin{tabular}{|c|c|c|c|c|c|}
\hline $\begin{array}{c}\text { Commercial } \\
\text { Wires }\end{array}$ & Model & Dimension & Country & $\begin{array}{c}\text { Batch } \\
\text { Number }\end{array}$ & $\begin{array}{c}\text { Number } \\
\text { of } \\
\text { Wires }\end{array}$ \\
\hline Ormco Corp. & $\begin{array}{c}\text { Cooper NiTi } \\
35^{\circ} \mathrm{C}\end{array}$ & $0.019 \times 0.025^{\prime \prime}$ & USA & 090924641 & 4 \\
\hline GAC & NeoSentalloy & $0.019 \times 0.025^{\prime \prime}$ & USA & K442 & 4 \\
\hline Orthometric & $\begin{array}{c}\text { Flexy } \\
\text { Thermal } \\
\text { Smart } 37^{\circ} \mathrm{C}\end{array}$ & $0.019 \times 0.025^{\prime \prime}$ & Brazil & 1008925208 & 4 \\
\hline $\begin{array}{c}\text { Highland } \\
\text { Metals }\end{array}$ & $\begin{array}{c}\text { Heat } \\
\text { Activated } \\
\text { NiTi Arches }\end{array}$ & $0.019 \times 0.025^{\prime \prime}$ & USA & 38222 & 4 \\
\hline
\end{tabular}

Specimen preparation for DSC analysis comprised sectioning of $8 \mathrm{~mm}$ segments from the premolar area (straighter portion of the arch) in each arch form. The segments weighed approximately $8 \mathrm{mg}$ on a precision electronic scale with $10 \mu \mathrm{g}$ accuracy (semi-analytical electronic scale, Sartorius, 60905472 Serial number, Goettingen, Germany). The specimens were obtained using a diamond saw connected to a pneumatic sectioning machine under cooling and at low speed in order to avoid mechanical stresses and heating that could alter the microstructure of the wire.

The tests were performed following the guidelines of the International Organization for Standardization (ISO), ISO 15 841 (ISO, 2006), and the American Society for Testing and Materials (ASTM), ASTM D3418-08 (ASTM, 2008). DSC (model Q20; TA Instruments, New Castle, DE, USA) was used for scanning of the thermally activated arch wires (Fig. 1).

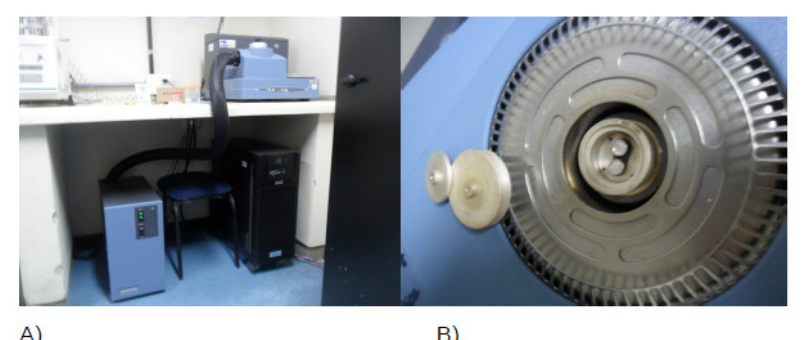

A)

B)

Fig. (1). A) DSC; B) An empty aluminum crucible served as the reference during the DSC measurements

Each specimen was reweighed in a precision electronic scale with $10 \mu \mathrm{g}$ accuracy, placed in an aluminum crucible, and sealed. An empty aluminum crucible was used as inert reference. DSC was calibrated prior to testing, and the heating chamber was filled with nitrogen atmosphere $(50 \mathrm{ml} / \mathrm{min})$ in order to prevent water condensation and oxidation of the material. The heating and cooling rates were determined at $10^{\circ} \mathrm{C} /$ min with temperatures ranging from $-80^{\circ} \mathrm{C}$ to $150^{\circ} \mathrm{C}$. All samples were subjected to two cycles to ensure complete heating and cooling of the alloy.

Graphs of the curves of the exothermic and endothermic reactions during cooling and warming, respectively, were obtained via the Platinum Software ${ }^{\circledR}$ (TA Instruments, New Castle, DE, USA), which demonstrated the manner in which the intersection of the tangents to peak slopes are used to determine various transition temperature points.

The temperatures and enthalpy changes related to phase transformations obtained in the DSC tests during cooling and heating is described in Tables $\mathbf{2}$ and $\mathbf{3}$.

\section{RESULTS}

Tables 2 and $\mathbf{3}$ show the results of DSC and the enthalpy for cooling and heating, respectively. Variations in the martensite start and end temperatures under the different conditions tested are shown in Table 2 . This TTR characterizes formation of the martensite phase of the thermal NiTi alloy. The alloys that were tested did not present large variations in temperatures in the different conditions analyzed.

In case of the heating endset measures, only small differences were observed between the wires "as received 1", "as received 2", "60 days in clinical use", and "60 days in clinical use + sterilization process" for each commercial brand, with exception of the Highland Metal archwires, which showed a difference of $7.75^{\circ} \mathrm{C}$ (Table 3). NeoSentalloy GAC appeared to be greatly influenced by the conditions tested in the heating onset.

Af is characterized by complete formation of the austenite phase in the thermal NiTi alloys and should be close to the oral temperature for better clinical applicability of the archwires. Orthometric Flexy Thermal $37^{\circ} \mathrm{C}$ presented with Af values closest to that of the oral cavity, which remained unchanged under the conditions tested (Table 4). 
Table 2. Differential scanning calorimetry-measured temperature and enthalpy changes for phase transformations during cooling of thermally activated Nickel-Titanium wires $\left({ }^{\circ} \mathrm{C}\right)$

\begin{tabular}{|c|c|c|c|c|}
\hline Commercial Wires & Condition & Cooling Onset $\left({ }^{\circ} \mathrm{C}\right)$ & Cooling Endset $\left({ }^{\circ} \mathrm{C}\right)$ & Enthalpy (J/g) \\
\hline Copper NITI ORMCO & "As received" 1 & 13.50 & -10.38 & 13.36 \\
\hline Copper NiTi ORMCO & "As received" 2 & 14.02 & -9.98 & 14.97 \\
\hline Copper NiTi ORMCO & "60 days in clinical use" & 13.69 & -10.55 & 13.50 \\
\hline Copper NiTi ORMCO & \begin{tabular}{|c|} 
"60 days in clinical use + \\
sterilization process"
\end{tabular} & 14.14 & -9.88 & 14.48 \\
\hline NeoSentalloy GAC & "As received" 1 & -22.39 & -59.44 & 5.96 \\
\hline NeoSentalloy GAC & "As received" 2 & -23.42 & -59.39 & 6.14 \\
\hline NeoSentalloy GAC & "60 days in clinical use" & -22.93 & -51.83 & 8.04 \\
\hline NeoSentalloy GAC & \begin{tabular}{|c|}
60 days in clinical use + \\
sterilization process"
\end{tabular} & -22.29 & -51.15 & 8.51 \\
\hline Orthometric Flexy Thermal $37^{\circ} \mathrm{C}$ & "As received" 1 & 17.80 & -0.48 & 17.88 \\
\hline Orthometric Flexy Thermal $37^{\circ} \mathrm{C}$ & "As received" 2 & 17.50 & -1.57 & 17.70 \\
\hline Orthometric Flexy Thermal $37^{\circ} \mathrm{C}$ & "60 days in clinical use" & 17.33 & -1.53 & 17.42 \\
\hline Orthometric Flexy Thermal $37^{\circ} \mathrm{C}$ & \begin{tabular}{|c|}
60 days in clinical use + \\
sterilization process"
\end{tabular} & 17.46 & -1.40 & 16.86 \\
\hline Highland Metals & "As received" 1 & -31.35 & -61.03 & 2.27 \\
\hline Highland Metal & "As received"2 & -32.90 & -52.41 & 0.30 \\
\hline Highland Metals & "60 days in clinical use" & -31.75 & -65.04 & 1.77 \\
\hline Highland Metals & $\begin{array}{c}\text { "60 days in clinical use }+ \\
\text { sterilization process" }\end{array}$ & -31.17 & -60.86 & 3.17 \\
\hline
\end{tabular}

Table 3. Differential scanning calorimetry-measured temperature and enthalpy changes for phase transformations during heating of thermally activated Nickel-Titanium wires $\left({ }^{\circ} \mathrm{C}\right)$

\begin{tabular}{|c|c|c|c|c|}
\hline Commercial Wires & Condition & Heating Onset $\left({ }^{\circ} \mathrm{C}\right)$ & Heating Endset $\left({ }^{\circ} \mathrm{C}\right)$ & Enthalpy $(\mathrm{J} / \mathrm{g})$ \\
\hline Copper NITI ORMCO & "As received" 1 & 9.04 & 31.16 & 12.91 \\
\hline Copper NiTi ORMCO & "As received" 2 & 8.96 & 30.96 & 14.29 \\
\hline Copper NiTi ORMCO & "60 days in clinical use" & 8.17 & 30.53 & 13.50 \\
\hline Copper NiTi ORMCO & \begin{tabular}{|c|}
60 days in clinical use + \\
sterilization process"
\end{tabular} & 8.86 & 31.20 & 14.23 \\
\hline NeoSentalloy GAC & "As received 1 & 13.79 & 30.72 & 17.53 \\
\hline NeoSentalloy GAC & "As received" 2 & 12.33 & 29.29 & 18.03 \\
\hline NeoSentalloy GAC & "60 days in clinical use" & 19.87 & 28.78 & 17.96 \\
\hline NeoSentalloy GAC & $\begin{array}{c}\text { "60 days in clinical use }+ \\
\text { sterilization process" }\end{array}$ & 19.92 & 28.80 & 17.96 \\
\hline Orthometric Flexy Thermal $37^{\circ} \mathrm{C}$ & "As received" 1 & 17.76 & 35.64 & 17.44 \\
\hline Orthometric Flexy Thermal $37^{\circ} \mathrm{C}$ & "As received " 2 & 17.16 & 35.42 & 16.80 \\
\hline Orthometric Flexy Thermal $37^{\circ} \mathrm{C}$ & "60 days in clinical use " & 17.38 & 35.32 & 16.62 \\
\hline Orthometric Flexy Thermal $37^{\circ} \mathrm{C}$ & $\begin{array}{c}60 \text { days in clinical use }+ \\
\text { sterilization process" }\end{array}$ & 17.38 & 35.50 & 16.51 \\
\hline Highland Metals & "As received" 1 & 10.98 & 32.81 & 16.42 \\
\hline Highland Metal & "As received"2 & 9.95 & 38.70 & 14.01 \\
\hline Highland Metals & "60 days in clinical use" & 10.44 & 30.95 & 16.63 \\
\hline Highland Metals & 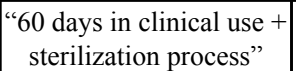 & 9.29 & 33.71 & 16.08 \\
\hline
\end{tabular}

Table 4. Austenite finish temperatures of thermally activated Nickel-Titanium wires $\left({ }^{\circ} \mathrm{C}\right)$

\begin{tabular}{|c|c|c|c|c|}
\hline Commercial Wires & “As Received” 1 & “As Received” 2 & “60 Days in Clinical Use” & $\begin{array}{c}\text { “60 Days in Clinical Use + Sterilization } \\
\text { Process” }\end{array}$ \\
\hline Copper NiTi ORMCO & 31.16 & 30.96 & 30.53 & 31.20 \\
\hline NeoSentalloy GAC & 30.72 & 29.29 & 28.78 & 28.80 \\
\hline
\end{tabular}


(Table 4) contd.....

\begin{tabular}{|c|c|c|c|c|}
\hline Commercial Wires & “As Received" 1 “As Received” 2 & “60 Days in Clinical Use” & $\begin{array}{c}\text { "60 Days in Clinical Use + Sterilization } \\
\text { Process" }\end{array}$ \\
\hline Orthometric Flexy Thermal $37^{\circ} \mathrm{C}$ & 35.64 & 35.42 & 35.32 & 35.50 \\
\hline Highland Metals & 32.81 & 38.70 & 30.95 & 33.71 \\
\hline
\end{tabular}

\section{DISCUSSION}

The different commercial brands used in this study were based upon the previous studies, which had evaluated the thermal transition interval of the wires using DSC and reported good results of the Af temperature [4, 7, 8]. Ren et al., evaluated the TTR of nine commercial thermal NiTi archwires and concluded that the temperature range varies according to the trademarks [9]. Another study evaluated TTR of seven NiTi archwires of $0.019 \times 0.025$-inch and concluded that the thermally activated NiTi archwires present great variability. In addition, the elastic parameters of each NiTi archwire should be provided by the manufacturers to allow achievement of the best clinical performance possible [8].

The present study was realized with thermally activated NiTi archwires $(0.019 \times 0.025$-inch $)$ because of its ability to present good control over tooth movement during leveling and alignment [10]. DSC used to measure the temperatures and enthalpies has been shown to be effective in several studies [5, $11,12]$, although there are other methods, such as conventional X-Ray Diffraction (XRD), that can be used to measure TTR $[9,11,13]$. Two-wires of each commercial brand were used as control to provide parameters that confirmed whether the changes in TTR had occurred because of clinical use and sterilization. Pompeii-Reynolds and Kanavakis [14] rated Af of Copper NiTi archwires $(0.016$ and $0.016 \times 0.022$-inch $)$ at temperatures of $27^{\circ} \mathrm{C}, 35^{\circ} \mathrm{C}$, and $40^{\circ} \mathrm{C}$; statistically significant differences were observed for the 0.016 -inch $/ 27^{\circ} \mathrm{C}(P=0.041)$ and $0.016 \times 0,022$-inch $/ 35^{\circ} \mathrm{C}(P=0.048)$ wires. The sterilization process using autoclave was chosen as the most commonly used method of sterilization by dentists in clinical practice [15].

Af temperature is of great clinical importance because it is at this temperature that the phase transformation of the thermally activated NiTi archwire occurs, thereby promoting leveling and alignment of the teeth [16]. Therefore, archwires with Af temperature closer to that of the oral cavity $\left(35^{\circ} \mathrm{C}-37^{\circ} \mathrm{C}\right)$ are considered to be the best choice $[17,18]$. The results of the present study showed that there was a little difference in Af temperature between the brands, except for Highland Metals, which presented with a variation of $7.75^{\circ} \mathrm{C}$ between the "as received" wires and "after clinical use" wires. Biermann et al. compared TTR of Copper NiTi at Af temperatures of $27^{\circ} \mathrm{C}$ and $35^{\circ} \mathrm{C}$ under the conditions "as received" and "used in the mouth for a period of 1-3 weeks" and did not find any statistical differences between the two [19]. In another study, the Af temperature nickel-titanium wires coated black oxide (Black Diamond $^{\mathrm{TM}}$ ) were evaluated by DSC machine in the forms "as received" and 60 days after clinical use. Statistically significant differences were not found in the thermal transition values in groups [20]. Several studies have evaluated the influence of the sterilization process on the mechanical properties of thermally activated NiTi wires $[6,15$, 21 - 23]; however, there are no studies on the influence of clinical use and the sterilization process on TTR of these NiTi archwires. A study by Alexandrou et al. [24], evaluated the influence of the sterilization process on TTR of 33 endodontic files made from NiTi alloy. They were subjected to 11 cycles of sterilization and proved that the sterilization process had no effect on the TTR of these files. When evaluating one cycle of sterilization in NiTi wires after its use for 60 days in the oral cavity, minor differences were obtained in Af temperatures between the samples " 60 days in clinical use" and " 60 days in clinical use + sterilization process" (Table 4).

The enthalpy values recorded in the study of thermoset NiTi wires show that there were minor differences between the different states of wires belonging to various trademarks. Because the enthalpy values are considered as a reliable indicator for phase transformations as demonstrated by Brantley et al. [25], these changes can be considered within normal limits. This implies that thermoset NiTi wires maintain their memory properties after clinical use and one cycle of sterilization.

\subsection{Clinical Implications}

The clinical importance of using thermally activated $\mathrm{NiTi}$ archwires is based on the fact that it allows for the insertion of rectangular wires during the early stages of leveling and alignment, resulting in a three-dimensional correction of tooth positioning. As the rectangular, thermally activated NiTi archwires are subjected to deflections of greater magnitude because of the presence of crowding, it requires more time of permanence in the oral environment. Because of the manufacturing process, the costs of these archwires are considered to be too high by the orthodontists, and some suggest sterilization of these wires through autoclave without knowledge of the changes that could occur on the wire properties.

Our results show that there are minor differences in the Af temperatures of the thermoactivated nickel-titanium archwires after 60 days of clinical use and after 1-cycle sterilization process, but these differences do not imply undesirable effects on shape memory property.

\section{CONCLUSION}

There was no clinical difference in the TTR of thermally activated NiTi wires after clinical use and 1-cycle sterilization process. More studies are needed to confirm this behavior of thermoactivated nickel-titanium alloys when subjected to more than one sterilization cycle and their influence on their physical and mechanical properties.

\section{LIST OF ABREVIATIONS}

$$
\begin{array}{lll}
\text { NiTi } & =\text { Nickel-Titanium } \\
\text { TTR } & =\text { Transition Temperature Range } \\
\text { Af } & =\text { Austenite Finish Temperature } \\
\text { DSC } & =\text { Differential Scanning Calorimetry }
\end{array}
$$


XRD X-Ray Diffraction

\section{ETHICS APPROVAL AND CONSENT TO PARTICIPATE}

Not applicable.

\section{HUMAN AND ANIMAL RIGHTS}

No animals/humans were used for studies that are the basis of this research.

\section{CONSENT FOR PUBLICATION}

Not applicable.

\section{STANDARDS OF REPORTING}

International Organization for Standardization (ISO), ISO 15841 (ISO, 2006) and American Society for Testing and Materials (ASTM), ASTM D3418-08 (ASTM, 2008) guidelines and methodology were followed.

\section{FUNDING}

None.

\section{AVAILABILITY OF DATA AND MATERIALS}

Data sharing is not applicable in this study as no new datasets were generated in the research.

\section{CONFLICT OF INTEREST}

The authors declare no conflict of interest, financial or otherwise.

\section{ACKNOWLEDGEMENTS}

This article is based on research submitted by Dr. Bruno Silva Vieira in partial fulfillment of the requirements for the MSc. degree in Orthodontics at Uningá Faculty. BSV contributed to patient treatment, data collection, statistical analyses, data interpretation and manuscript draft. RHC contributed to project idealizer, research supervisor. KMSF contributed to data checking, manuscript draft and corrections. FPV contributed to data checking, manuscript draft and corrections. RCG contributed to data checking, manuscript draft and corrections. RCGB contributed to data checking, manuscript draft and corrections. All authors read and approved the final manuscript.

\section{REFERENCES}

[1] Kapila S, Sakima T, Miyazaki S, Sachdeva R. Currently used orthodontic alloys. Review (1). Rev Odontol Univ Sao Paulo 1990; 4(4): 334-42. [PMID: 2135450]

[2] Miura F, Mogi M, Ohura Y, Hamanaka H. The super-elastic property of the Japanese NiTi alloy wire for use in orthodontics. American journal of orthodontics and dentofacial orthopedics : Official publication of the American Association of Orthodontists, its constituent societies, and the American Board of Orthodontics. 1986; 90: $1-10$.

[http://dx.doi.org/10.1016/0889-5406(86)90021-1]

[3] Bradley TG, Brantley WA, Culbertson BM. Differential Scanning Calorimetry (DSC) analyses of superelastic and nonsuperelastic nickel-titanium orthodontic wires. American journal of orthodontics and dentofacial orthopedics: Official publication of the American
Asso-ciation of Orthodontists, its constituent societies, and the American Board of Orthodontics. 1996; 109: 589-97.

[4] Iijima M, Ohno H, Kawashima I, Endo K, Mizoguchi I. Mechanical behavior at different temperatures and stresses for superelastic nickeltitanium orthodontic wires having different transformation temperatures. Dent Mater 2002; 18(1): 88-93.

[http://dx.doi.org/10.1016/S0109-5641(01)00025-2] [PMID: 117409 69]

[5] Meling TR, Odegaard J. Short-term temperature changes influence the force exerted by superelastic nickel-titanium archwires activated in orthodontic bending. American journal of orthodontics and dentofacial orthopedics: Official publication of the American Association of Orthodontists, its constituent societies, and the American Board of Orthodontics. 1998; 114: 503-9.

[http://dx.doi.org/10.1016/S0889-5406(98)70169-6]

[6] Buckthal JE, Mayhew MJ, Kusy RP, Crawford JJ. Survey of sterilization and disinfection procedures. J Clin Orthod 1986; 20(11): 759-65.

[PMID: 3466896]

[7] Berzins DW, Roberts HW. Phase transformation changes in thermocycled nickel-titanium orthodontic wires. Dent Mater 2010; 26(7): 666-74.

[http://dx.doi.org/10.1016/j.dental.2010.03.010] [PMID: 20371115]

[8] Spini TS, Valarelli FP, Cancado RH, Freitas KM, Villarinho DJ. Transition temperature range of thermally activated nickel-titanium archwires. J appl oral sci 2014; 22: 109-7.

[http://dx.doi.org/10.1590/1678-775720130133]

[9] Ren CC, Bai YX, Wang HM, Zheng YF, Li S. Phase transformation analysis of varied nickel-titanium orthodontic wires. Chin Med J (Engl) 2008; 121(20): 2060-4.

[http://dx.doi.org/10.1097/00029330-200810020-00022] [PMID: 190 80276]

[10] Pun DK, Berzins DW. Corrosion behavior of shape memory, superelastic, and nonsuperelastic Nickel-titanium-based orthodontic wires at various temperatures. Dent Mater 2008; 24(2): 221-7.

[http://dx.doi.org/10.1016/j.dental.2007.05.003] [PMID: 17624421]

[11] Laino G, De Santis R, Gloria A, et al. Calorimetric and thermomechanical properties of titanium-based orthodontic wires: DSC-DMA relationship to predict the elastic modulus. J Biomater Appl 2012; 26(7): 829-44.

[http://dx.doi.org/10.1177/0885328210388678] [PMID: 21343211]

[12] Seyyed Aghamiri SM, Ahmadabadi MN, Raygan Sh. Combined effects of different heat treatments and $\mathrm{Cu}$ element on transformation behavior of NiTi orthodontic wires. J Mech Behav Biomed Mater 2011; 4(3): 298-302.

[http://dx.doi.org/10.1016/j.jmbbm.2010.10.008] [PMID: 21316617]

[13] Iijima M, Brantley WA, Kawashima I, et al. Micro-X-ray diffraction observation of nickel-titanium orthodontic wires in simulated oral environment. Biomaterials 2004; 25(1): 171-6.

[http://dx.doi.org/10.1016/S0142-9612(03)00473-3] [PMID: 14580 920]

[14] Pompei-Reynolds RC, Kanavakis G. Interlot variations of transition temperature range and force delivery in copper-nickel-titanium orthodontic wires. Am J Orthodont Dentofac Orthoped 2014; 146: 215-6.

[http://dx.doi.org/10.1016/j.ajodo.2014.05.017]

[15] Mayhew MJ, Kusy RP. Effects of sterilization on the mechanical properties and the surface topography of nickel-titanium arch wires. Am J Orthodont Dentofac Orthoped 1988; 93: 232-6.

[16] Gurgel JA, Kerr S, Powers JM, LeCrone V. Force-deflection properties of superelastic nickel-titanium archwires. Am J Orthodont Dentofac Orthoped 2001; 120: 378-82.

[http://dx.doi.org/10.1067/mod.2001.117200]

[17] Dalstra M, Melsen B. Does the transition temperature of Cu-NiTi archwires affect the amount of tooth movement during alignment? Orthod Craniofac Res 2004; 7(1): 21-5.

[http://dx.doi.org/10.1046/j.1601-6335.2003.00275.x] [PMID: 1498 9751]

[18] Meling TR, Odegaard J. The effect of short-term temperature changes on superelastic nickel-titanium archwires activated in orthodontic bending. Am J Orthodont Dentofac Orthoped 2001; 119: 263-73. [http://dx.doi.org/10.1067/mod.2001.112451]

[19] Biermann MC, Berzins DW, Bradley TG. Thermal analysis of asreceived and clinically retrieved copper-nickel-titanium orthodontic archwires. Angle Orthod 2007; 77(3): 499-503. [http://dx.doi.org/10.2319/0003-3219(2007)077[0499:TAOAAC]2.0.C O;2] [PMID: 17465660] 
[20] Krishnan M, Seema S, Sukumaran K, Pawar V. Phase transitions in coated nickel titanium arch wires: A differential scanning calorimetric and X-ray diffraction analysis. Bull Mater Sci 2012; 35: 905-11.

[http://dx.doi.org/10.1007/s12034-012-0352-0]

[21] Kapila S, Reichhold GW, Anderson RS, Watanabe LG. Effects of clinical recycling on mechanical properties of nickel-titanium alloy wires. Am J Orthodont Dentofac Orthoped 1991; 100: 428-35.

[http://dx.doi.org/10.1016/0889-5406(91)70082-8]

[22] Pernier C, Grosgogeat B, Ponsonnet L, Benay G, Lissac M. Influence of autoclave sterilization on the surface parameters and mechanical properties of six orthodontic wires. Eur J Orthod 2005; 27(1): 72-81. [http://dx.doi.org/10.1093/ejo/cjh076] [PMID: 15743866]

[23] Staggers JA, Margeson D. The effects of sterilization on the tensile strength of orthodontic wires. Angle Orthod 1993; 63(2): 141-4. [PMID: 8498702]

[24] Alexandrou G, Chrissafis K, Vasiliadis L, Pavlidou E, Polychroniadis EK. Effect of heat sterilization on surface characteristics and microstructure of Mani NRT rotary nickel-titanium instruments. Int Endod J 2006; 39(10): 770-8

[http://dx.doi.org/10.1111/j.1365-2591.2006.01147.x] [PMID: 1694 8662]

[25] Brantley WA, Svec TA, Iijima M, Powers JM, Grentzer TH Differential scanning calorimetric studies of nickel-titanium rotary endodontic instruments after simulated clinical use. J Endod 2002; 28(11): 774-8.

[http://dx.doi.org/10.1097/00004770-200211000-00007] [PMID: 12 470023]

C) 2019 da Silva Vieira et al.

This is an open access article distributed under the terms of the Creative Commons Attribution 4.0 International Public License (CC-BY 4.0), a copy of which is available at: (https://creativecommons.org/licenses/by/4.0/legalcode). This license permits unrestricted use, distribution, and reproduction in any medium, provided the original author and source are credited. 